\title{
Enzymatic potential and biosurfactant production by endophytic fungi from mangrove forest in Southeastern Brazil
}

\author{
Vivian Martinho ${ }^{1}$ (), Lidiane Maria dos Santos Lima ${ }^{1}$, Caroline Almeida Barros ${ }^{1}$, Vitor Baptista Ferrari ${ }^{1}$, \\ Michel Rodrigo Zambrano Passarini ${ }^{2}$, Leonardo André Santos ${ }^{1}$, Fernanda Luisa de Souza Sebastianes ${ }^{3}$, \\ Paulo Teixeira Lacava ${ }^{3}$ and Suzan Pantaroto de Vasconcellos ${ }^{1 *}$ (1)
}

\begin{abstract}
Microbial activity is the main route for cycling mangrove nutrients. In general, microorganisms have abilities to degrade lignocellulosic compounds. Among the biotechnological potential of the microbiota from mangroves, it is noteworthy about endophytic fungi, which can be considered as effective sources of different bioactive compounds. In this sense, thirty (30) endophytic fungi were isolated from mangrove forest sampling Cananeia, SP, Brazil. These microorganisms were analyzed about their enzymatic activities including: lignin peroxidase EC 1.11.1.14, manganese peroxidase EC 1.11.1.13 and laccase EC 1.10.3.2, as well endo-cellulase EC 3.2.1.4 and endo-xylanase EC 3.2.1.8. Besides that, production of bioactive secondary metabolites like biosurfactant and/or bioemulsifier was also investigated. As results, nineteen (19) isolates were selected about their ligninolytic abilities, nine (9) of them about cellulase activity and thirteen (13) showed xylanase abilities. The fungal isolate named as 3(3), characterized as Fusarium sambucinum, showed a prominent lignin peroxidase $\left(42.4 \mathrm{U} \mathrm{L}^{-1}\right)$ and manganese peroxidase $\left(23.6 \mathrm{U} \mathrm{L}^{-1}\right)$ activities. The isolate 63.1, also related to Fusarium sp. genera, was selected about its laccase activity $\left(41.5 \cup \mathrm{L}^{-1}\right)$. From all the investigated fungi, the isolate 47(4) Trichoderma camerunense was selected about its cellulolytic and xylanolytic activities, showing 45.23 and $26.09 \mathrm{U} \mathrm{mL}^{-1}$, respectively. The same fungi also showed biosurfactant ability demonstrated by superficial tension decreasing to $38 \mathrm{mN} / \mathrm{m}$. In addition, fifteen (15) fungi exhibited bioemulsifier activity, with $\mathrm{E}_{24}$ values up to $62.8 \%$.
\end{abstract}

Keywords: Bioethanol, Biosurfactant, Cellulases, Ligninases, Xylanases

\section{Introduction}

Mangroves are coastal ecosystems with high production of organic matter to adjacent coastal waters (Badola et al. 2008). It is estimated that they cover around 18.1 million ha worldwide (Andreote et al. 2012). Microbial activity is the main route of nutrient cycling in mangroves (Kristensen et al. 2008; Sousa et al. 2006). Among different types of microorganisms at mangroves is worth mention

\footnotetext{
*Correspondence: suzan.pantaroto@unifesp.br

1 Department of Pharmaceutical Sciences, Federal University of São Paulo (UNIFESP), R. São Nicolau, 210, Diadema, SP Zip Code 09913-030, Brazil

Full list of author information is available at the end of the article
}

about the endophytic fungi, whose can establish mutualistic associations with plants (Schwarz et al. 2004).

These microorganisms can exhibit biochemical versatility and biological diversity, which have revealed dense variety of genes with important biotechnological applications (Sebastianes et al. 2013), including the production of ligninases, cellulases and xylanases (Zheng et al. 2016; Bezerra et al. 2012; Rajulu et al. 2011).

Conventional ethanol production or first-generation ethanol is produced by fermentation of sugarcane juice by Saccharomyces cerevisiae (Peixoto et al. 2012). Although the production of second-generation ethanol, or lignocellulosic bioethanol from biomass, are processes that need efficient enzyme-producing 
microorganisms to perform the extraction of all polysaccharides. For this, it is required the use of different enzymes, including oxidases and hydrolases (Manavalan et al. 2015; Aguiar and Ferraz 2011).

Lignin peroxidases (EC 1.11.1.14) are able to oxidize benzyl alcohols, breakdown aromatic chains, perform intramolecular rearrangements, and break rings into non-phenolic compounds related to lignin (Rabonato 2013). They can be used in waste treatment, as well as the catalysis of difficult chemical transformations (Akbar et al. 2013). Manganese peroxidase (EC 1.11.1.13) is manganese dependent enzyme that oxidizes organic substrates, such as phenols and phenyl radicals (Durán 2010). Laccase (EC 1.10.3.2) can oxidize different compounds, such as phenolic dyes, phenols, chlorophenols, diphenylmethanes, benzopyrenes, organophosphorus and other compounds with similar molecular structures to lignin (Shraddha et al. 2011).

Endo-1,4- $\beta$-D-glucanase (cellulase) (EC 3.2.1.4) promotes the hydrolysis of $\beta-1,4$ bonds in the amorphous regions of cellulose molecules, decreasing the degree of polymerization, exposing the microfibrils to other enzymatic attacks. Currently, fungal cellulases are used at industrial processes, emphasizing the hydrolysis of lignocellulosic biomass (Wang et al. 2012; Zhao et al. 2012). Endo-1,4- $\beta$-xylanase (xylanase) (EC 3.2.1.8) hydrolyses $\beta-1,4$ bonds of xylan substrate, also promoting the decreasing of polymerization degree (Aro et al. 2005). Filamentous fungi present high levels of xylanase when compared to yeasts and bacteria (Polizeli et al. 2011).

In another context, biosurfactants and bioemulsifiers can be employed for bioremediation of areas contaminated by oil, especially petroleum. These compounds are amphiphilic molecules with dual affinity (polar-apolar), which can be microbially produced (Pacwa-Plociniczak et al. 2011; Soberón-Chávez and Maier 2011). They are secreted either extracellular or attached to cell parts, predominantly during growth on water-immiscible substrates. This happens because the biosurfactants can reduce the surface tension at the boundary phase on water-immiscible substrates, making the substrate more readily available for uptake and microbial metabolism (Desai and Banat 1997).

Microorganisms that produce these bioactive secondary metabolites can have greater ability in the digestibility of vegetal biomass. According to microbial versatility and different possibilities to investigate this topic, the present study aimed to show some technological potential of endophytic fungi to produce not only enzymes, but also some exopolymers with biosurfactant and/or bioemulsifier activities.

\section{Materials and methods Endophytic strains}

All the endophytic fungi isolates evaluated in this study were deposited at Culture Collection the Laboratory of Microbiology and Biomolecules, from the Department of Morphology and Pathology, at Federal University of São Carlos-UFSCar. The isolate 47(4), characterized as Trichoderma camerunense was deposited at Brazilian Culture Collection of Microorganisms from Environment and Industry (CBMAI/UNICAMP): CBMAI 2095. These endophytes were isolated from Cananeia $\left(25^{\circ} 05^{\prime} 02^{\prime} \mathrm{S}, 47^{\circ} 57^{\prime} 42^{\prime} \mathrm{W}\right)$ mangrove forest, located at São Paulo, Brazil. Sebastianes (2010) and Sebastianes et al. (2013) described and characterized these fungi, previously. Cananeia mangrove forest is a natural reserve covering an area of 15,100 ha. Brazilian government named this site as natural reserve on July 3,1962. This reserve contains mangroves and several other coastal ecosystems, including Atlantic Rainforest and Restinga, as well an inland forest (Sebastianes et al. 2013; Dias et al. 2010).

\section{Activities of ligninases}

Preliminarily, ligninolytic enzyme activities were performed in a qualitative approach. Thus, all fungal isolates were cultured in BKG agar (glucose $10.0 \mathrm{~g} \mathrm{~L}^{-1}$; peptone $2.0 \mathrm{~g} \mathrm{~L}^{-1}$; yeast extract $1.0 \mathrm{~g} \mathrm{~L}^{-1}$; agar $20.0 \mathrm{~g} \mathrm{~L}^{-1}$ and guaiacol $4 \mathrm{mM}$ ). This screening is based on the microbial oxidation of guaiacol (Sigma Aldrich ${ }^{\circledR}$ ) by ligninolytic enzymes after 4 to 7 days incubation at $28{ }^{\circ} \mathrm{C}$, checking the color change of the medium from yellow to brown (D'Souza-Ticlo et al. 2006).

Positive hits in these qualitative analyses were conducted to a second round of investigation, using spectrophotometric assays aiming to quantify Lignin Peroxidase (LiP; EC 1.11.1.14), Manganese Peroxidase (MnP; EC 1.11.1.13) and Laccase (Lac; EC 1.10.3.2), after 7 days of incubation in a rotating shaker at $28{ }^{\circ} \mathrm{C}$ in ME (Malt Extract Oxoid $^{\circledR}$ ) broth 3\%, in triplicates.

LiP activity was quantified using the adapted methodology from Arora and Gill (2001). It was analyzed the oxidation of veratryl alcohol (Sigma Aldrich ${ }^{\circledR}$ ) to veratryl aldehyde, in the presence of $\mathrm{H}_{2} \mathrm{O}_{2}$. For the analysis of $\mathrm{MnP}$, it was adopted a modified method of Kuwahara et al. (1984). MnP was determined by measuring the oxidation rate of phenol red substrate, in the presence of $\mathrm{H}_{2} \mathrm{O}_{2}$. Lac analyses were performed according to method described by De Pinto and Ros Barceló (1996), based on the oxidation of guaiacol.

All spectrophotometric measurements were performed using a microplate reader (Biotek Synergy HT, USA). Negative control was composed by the culture medium without the microbial inoculum. One unit of enzyme 
activity (U) was defined as the amount of enzyme needed to generate one (1) $\mu \mathrm{mol}$ of product reaction per minute.

\section{Stablishment of optimal enzymatic conditions}

Aiming to stablish optimal conditions for ligninolytic activities, analyzes at different temperatures and $\mathrm{pH}$ ranges were performed, using an adaptation of the method developed by Heuts et al. (2007). Such analyzes were just conducted to selected strain, which could showed some prominent ligninolytic activities, at the preliminarily described assays. The reactions were conducted at the following temperatures: 37.0 and $45.0^{\circ} \mathrm{C}$, at pH 2.0 to 9.0.

\section{Cellulase and xylanase activities}

Endo-cellulase (endo-1,4- $\beta$-D-glucanase; EC 3.2.1.4) and endo-xylanase (endo-1,4-beta-xylanase; EC 3.2.1.8) activities were monitored with commercial kits AZO-CM-Cellulose and AZO-XYLAN-BIRCHWOOD (Megazyme ${ }^{\circledR}$ International, Bray, Ireland), respectively. For both analyzes, the 30 isolated were inoculated for 4 days in ME supplemented by $10.0 \mathrm{~g} \mathrm{~L}^{-1}$ cellulose (Celuflok $100^{\circledR}$ ) for the cellulase activity, or $10.0 \mathrm{~g} \mathrm{~L}^{-1}$ xylan (Sigma ${ }^{\circledR} \mathrm{X} 4252$ ) for the xilanase, in triplicate.

Absorbance measurements were developed using a spectrophotometer UV/Vis (BioTek Synergy HT, USA). Negative control was composed by the culture medium, non-inoculated by the fungal strains. Calculation of activities and positive control (Trichoderma reesei-RUT C30) were performed according to the manufacturer's specifications.

\section{Biosurfactant and bioemulsifier production assays}

For screening of biosurfactant-producing isolates, all fungi were analyzed by qualitative drop-collapse technique, described by Boudour and Miller-Maier (1998). The fungal isolates were incubated, in triplicate, at ME, during $96 \mathrm{~h}$. Then, the supernatant aliquots were analyzed about the presence or absence of biosurfactant activities, when spoted in the center of a thin coat of automotive engine oil disposed at polystyrene lid of a 96-microwell plate, with diameter of $8 \mathrm{~mm}$. If the drop remained beaded, it was considered a negative hit. However, if the drop was collapsed, it was get a positive hit. Non-inoculated culture medium was used as negative control, while Tween $80\left(\operatorname{Synth}^{\circledR}\right)$ 2\% solution was applied as positive control.

\section{Emulsification Indexes $\left(E_{24}\right)$}

The positive hits selected at drop-collapse assay were evaluated about their emulsification abilities, using three different apolar compounds (soy oil, automotive engine oil and hexane $85 \%$ ). The isolates were cultured at ME medium during 4 days, in triplicate. Besides that, the supernatants were examined about bioemulsifiers production, according Cooper and Goldenberg (1987) methodology. The $\mathrm{E}_{24}$ indexes were calculated according to Fleck et al. (2000), and described as percentage values. The culture medium without inoculum was also adopted as negative control, while solution of Tween $80(10 \%)$ was used as positive control.

\section{Tensiometric analysis}

Positive hits obtained through drop collapse technique, were also evaluated about their tensiometric abilities, using the ring method, according to methodology described by Rodrigues et al. (2006). Therefore, the selected isolates were inoculated in the mineral medium supplemented with saccharose $\left(5.0 \mathrm{~g} \mathrm{~L}^{-1}\right)$, soy oil $\left(5.0 \mathrm{~mL} \mathrm{~L}^{-1}\right)$, peptone $\left(2.5 \mathrm{~g} \mathrm{~L}^{-1}\right)$ and yeast extract $\left(2.5 \mathrm{~g} \mathrm{~L}^{-1}\right)$, during 4 days, in triplicate. The analysis were based in the measurement of surface tension of microbial supernatants $(\mathrm{mN} / \mathrm{m})$ using a Krüss $\mathrm{K} 6$ tensiometer. The negative control was uninoculated culture medium.

\section{Results \\ Ligninolytic activities}

Using qualitative screening applying Guaiacol Agar (BKG) medium, nineteen (19) fungal isolates showed some ligninolytic activities. As illustrated through Fig. 1, the obtained positive hits exhibited brown color under and/or around their colonies, confirming the microbial guaiacol oxidation reaction. Then, after these qualitative screening, the positive hits were analyzed about the specific activities of lignin peroxidase (LiP), manganese peroxidase $(\mathrm{MnP})$ and laccase $(\mathrm{Lac})$ using spectrophotometric assays.

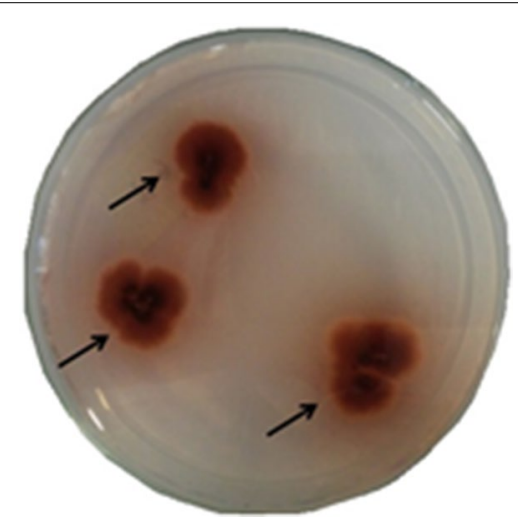

Fig. 1 Illustrative image of a positive hit cultured in guaiacol agar $(\mathrm{BKG})$. The arrows show the color change of the medium (yellow to brown), which indicates the oxidation of guaiacol by the action of the ligninolytic enzymes produced by the isolated. It is the result of 16.1-Fusarium sp. 
LiP analysis, revealed satisfactory results for fungi 3(3)-Fusarium sambucinum and 67(4)-Diaporthe sp., showing $42.4 \mathrm{U} \mathrm{L}^{-1}$ and $36.2 \mathrm{U} \mathrm{L}^{-1}$, respectively. Three (3) isolated (12.6, 47.4 and 1.14) showed LiP activities ranging from 15.9 to $14.5 \mathrm{U} \mathrm{L}^{-1}$. All of the 19 evaluated fungi could showed some MnP activities. In this context, the isolates 3(3)-F. sambucinum and 12.2(1)-Diaporthe sp.

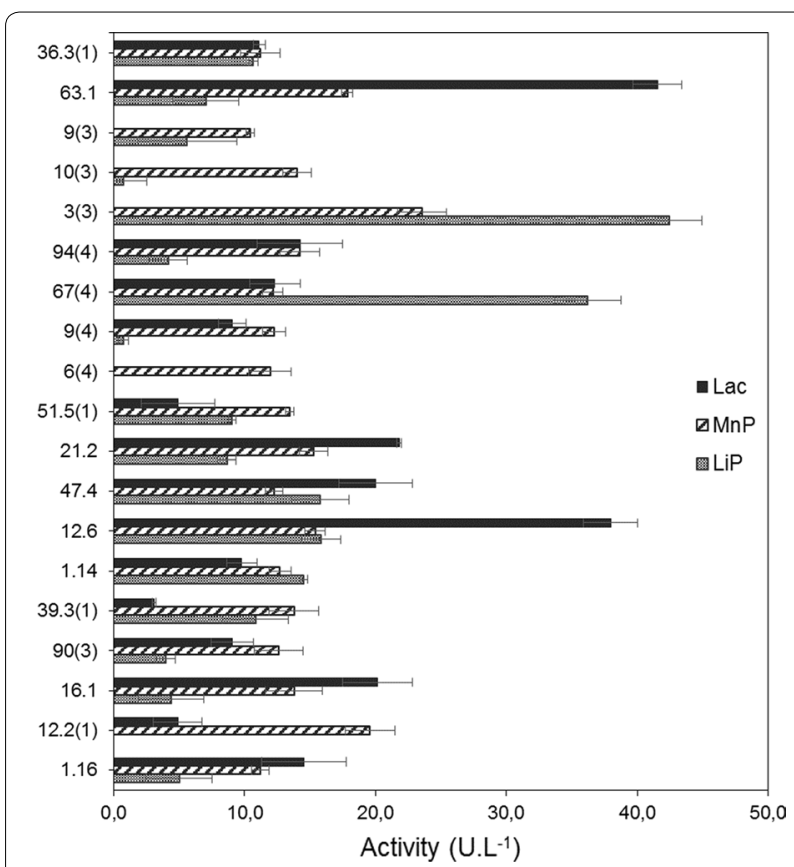

Fig. 2 Ligninolytic activity of lignin peroxidase (LiP; EC 1.11.1.14), manganese peroxidase (MnP; EC 1.11.1.13) and laccase (Lac; EC 1.10.3.2) assays, values in $U L^{-1}$. Results about the fungi selected positive in qualitative screening with guaiacol used like the substrate. Lac assays of isolates 9(4) and 3(3) unrealized. The data represent the means and standard errors of three measurements reached the highest activity values, 23.6 and $19.6 \mathrm{U} \mathrm{L}^{-1}$, respectively. In addition, about Lac activities, the isolates 63.1-Fusarium sp. and 12.6-Hypocrea lixii showed the highest performances, $41.5 \mathrm{U} \mathrm{L}^{-1}$ and $38.0 \mathrm{U} \mathrm{L}^{-1}$, respectively (Fig. 2).

\section{Stablishment of optimal enzymatic conditions}

It was selected the isolated 3(3)-Fusarium sambucinum as a model microorganism to optimize reaction conditions, in order to improve its ligninolytic abilities. This isolated was adopted as it showed prominent LiP and $\mathrm{MnP}$ activities, in the previous described analysis. In this context, a pH range between 2.0 and 9.0, under three (3) temperatures $\left(22,37\right.$ and $\left.45^{\circ} \mathrm{C}\right)$ were evaluated. $\mathrm{MnP}$ activities showed some variated values, if compared to LiP activities. It was obtained $\mathrm{pH} 9.0$ at $37{ }^{\circ} \mathrm{C}$, as the optimum conditions for LiP activity. For MnP enzyme, $\mathrm{pH} 5.0$ at $45{ }^{\circ} \mathrm{C}$ was detected as the optimum condition (Fig. 3).

\section{Cellulolytic and xylanolytic activities}

All the 30 endophytic fungi were investigated about their endo-cellulase and endo-xylanase activities. Fifteen (15) fungi showed either cellulase or xylanase activities. Nine (9) isolates showed cellulolytic activities. Three (3) of them showed better performance than adopted positive control [47(4), 12.2(1) and 36.3(1)]. Thirteen (13) fungi could demonstrated some xylanolytic ability, emphasizing four (4) isolates that showed results comparable to positive control [47(4), 82(4), 51.5(1) and 36.3(1)]. The most standout cellulolytic and xylanolitic activities were showed by the isolated 47(4)-Trichoderma camerunense, which is affiliated with the same genera of the positive control Trichoderma reesei (Fig. 4).
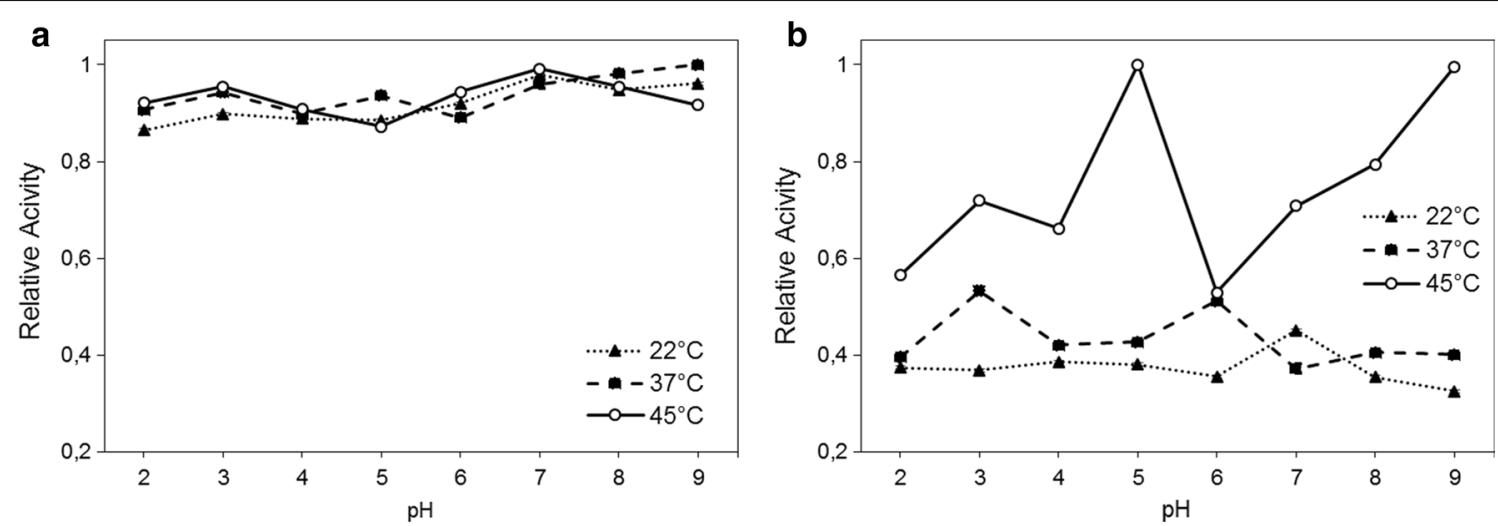

Fig. 3 Relative activity of strain 3(3) — Fusarium sambucinum about its ligninolytic activities in pH range to 2.0-9.0 and three (3) temperatures (22, 37 and $45^{\circ} \mathrm{C}$ ) for stablish optimal conditions. a Lignin peroxidase (LiP) using veratryl alcohol like substrate and $\mathbf{b}$ manganese peroxidase (MnP) with phenol red was used as substrate these analyses. The data represent the means and standard errors of three measurements 


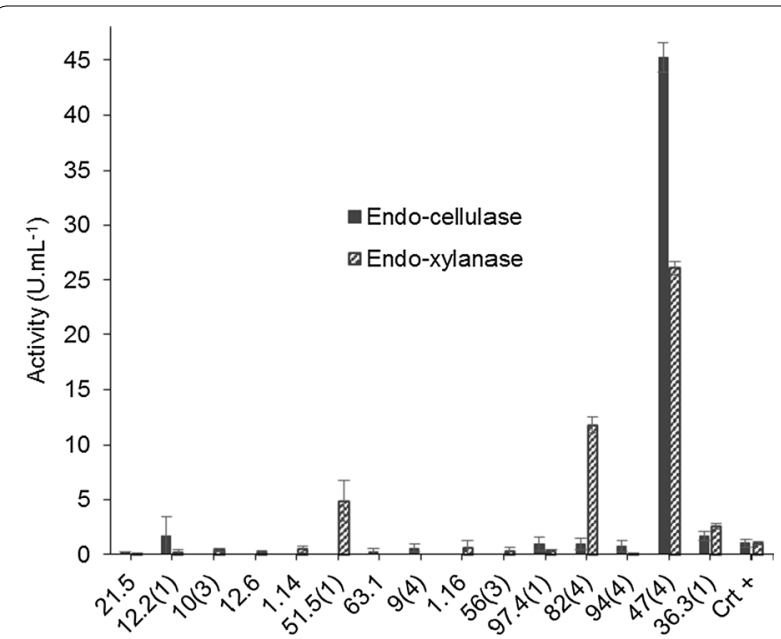

Fig. 4 Endo-cellulases (endo-1,4- $\beta$-D-glucanase; EC 3.2.1.4) and endo-xilanases (endo-1,4-beta-xylanase; EC 3.2.1.8) activities, expressed in $\mathrm{U} \mathrm{mL}^{-1}$, of positive fungi for commercial kits AZO-CM-Cellulose and AZO-XYLAN-BIRCHWOOD (Megazyme ${ }^{\circledR}$ International, Bray, Ireland), respectively. Positive control performed according to the manufacturer's specifications, using a strain of Trichoderma reesei-RUT C30. The data represent the means and standard errors of three measurements

\section{Biosurfactant and bioemulsifier activities}

Through qualitative drop collapse screening it was possible to select fifteen (15) positive hits. Besides that, these selected fungi were analyzed about their potential to produce bioemulsifier compounds, calculating their Emulsification Indexes $\left(\mathrm{E}_{24}\right)$ under non polar compounds. All the evaluated fungi could show some ability to emulsify automotive engine oil and soybean oil, while eight (8) isolates were able to emulsify $n$-hexane.

When automotive engine oil was used to evaluate the emulsifier potential of the fungi, it was possible to verify the most prominent $\mathrm{E}_{24}$ values, up to $62.8 \%$, by the isolates 94(4)-Diaporthe sp. and 9(4)-Aspergillus awamori. Against commercial soybean oil, two isolates showed the most expressive emulsifier activities, above de positive control: 63.1-Fusarium sp. (50.0\%) and 56(3)-Aspergillus niger (47.8\%). For $\mathrm{n}$-hexane, the best results were obtained by 75(3)-Fusarium chlamydosporum (51.9\%) and 56(3)-Aspergillus niger (38.4\%), above de positive control. Figure 5 illustrates the obtained $\mathrm{E}_{24}$ indexes under all the investigated compounds.

In this study, it was possible to select fifteen fungi about their emulsifying ability. All of them were also evaluated by tensiometric analyzes. Exception for the isolate 56(3)-Aspergillus niger, all of them showed some surfactant abilities. It is worth noting about the isolated 63.1-Fusarium sp. and 39.3(1)-Xylaria enteroleuca, which achieved the most prominent surface tension,

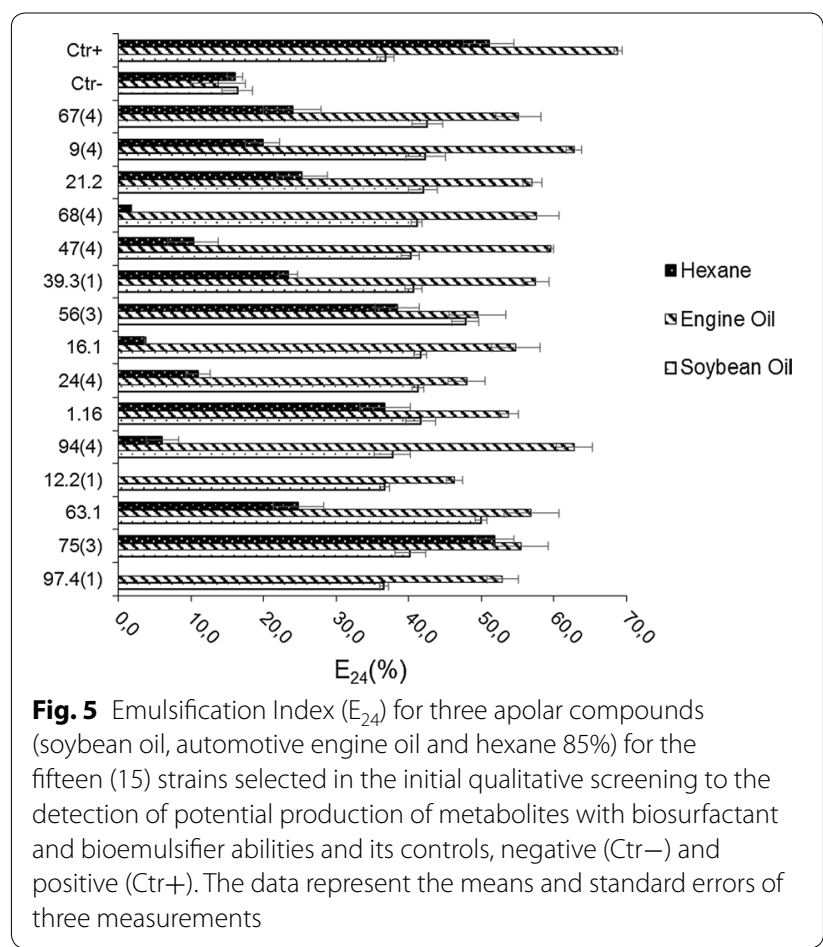

$36.0 \mathrm{mN} / \mathrm{m}$, followed by $47(4)$ - Trichoderma camerunense, $38 \mathrm{mN} / \mathrm{m}$.

\section{Discussion}

Industrial and environmental applications of ligninolytic enzymes are diverse and for this reason a number of studies about these enzymes are found. Although it is worth noting the studies with fungi of the genus Fusarium sp., Diaporthe sp., Hypocrea sp. (Tooley and Roberts 2016; Gajera et al. 2015; Lozovaya et al. 2006), which showed higher ligninolytic activities in this study. Bonugli-Santos et al. (2012) analyzed ligninolytic enzymes in three marine-derived basidiomycetes, and showed the highest LiP activity (2.234 $\mathrm{U} \mathrm{L}^{-1}$ ) for Tinctoporellus sp., as well highest MnP activity (4.514 $\mathrm{U} \mathrm{L}^{-1}$ ) for Marasmiellus sp. Silva et al. (2014) observed $117.33 \mathrm{U} \mathrm{L}^{-1}$ for MnP activity by Trametes villosa. About Lac activity, Stoilova et al. (2010) described, approximately, $1.7 \mathrm{U} \mathrm{L}^{-1}$ also for Trametes genus.

In the stablishment of optimal enzymatic conditions for LiP and MnP enzymes, it was observed the same patterns, which means the presence of more than one point of high activity. It was probable due the analyses were performed using the microbial supernatants, which may consist of a mixture of metabolites that influence the enzymatic activities, including the presence isoforms of enzymes that differ in the amino acid sequence and may present different optimal $\mathrm{pH}$ ranges 
and temperatures (Fernández-Fueyo et al. 2014). Moreover, the assays showed that optimal enzymatic conditions for manganese peroxidase were performed in similar $\mathrm{pH}$, while the increase in temperature resulted in an improvement in its activity. However, for lignin peroxidase, changes of $\mathrm{pH}$ and temperature increased its activity.

Evaluating cellulolytic and xylanolytic activities, Gouvêa (2013) showed values between 1.0 and $1.5 \mathrm{U} \mathrm{mL}^{-1}$ for cellulase, as well 7.5 to $10.0 \mathrm{U} \mathrm{mL}^{-1}$ for xylanase by an Aspergillus niger strain. In a similar study evaluating another $A$. niger strain, it was obtained values up to $18 \mathrm{U} \mathrm{mL}^{-1}$ and $216 \mathrm{U} \mathrm{mL}^{-1}$ for cellulase and xylanase activities, respectively (Bansal et al. 2011). Michelin et al. (2010) reported xylan-degrading activities between 1.5 to $11.0 \mathrm{U} \mathrm{mL}^{-1}$ and 2.0 to $10.95 \mathrm{U} \mathrm{mL}^{-1}$, for Aspergillus terricola and A. ochraceus, respectively. Gottschalk et al. (2013) investigated xylanolytic activity in a mutant strain of $A$. awamori reached $12.9 \mathrm{U} \mathrm{mL}^{-1}$ as the maximal xylanase activity, using yeast extract as nitrogen source.

Therefore, comparing the obtained results with the literature, it was possible to select the strain 47(4)-Trichoderma camerunense as a potential cellulase (45.23 $\mathrm{U} \mathrm{mL}^{-1}$ ) and xylanase $\left(26.09 \mathrm{U} \mathrm{mL}^{-1}\right.$ ) producer. According to the literature, there are microorganisms that can produce both enzymes, as described by Das et al. (2013), whose showed cellulolytic and xylanolytic activities for Aspergillus fumigatus. It is worth to mention that the main efforts into improve the production of second generation ethanol are focused in the cellulolytic and xylanolytic activities under lignocellulosic substrates (Mabee and Saddler 2010). Furthermore, there are many studies about cellulose activity with different species of Trichoderma sp. (Iqbal et al. 2011; Kirk et al. 2002). Iqbal et al. (2011) related a cellulase activity of $398 \mathrm{U} \mathrm{mL}^{-1}$ of Trichoderma viride.

Among the fifteen (15) fungi that showed ability to produce bioactive secondary metabolites (biosurfactant and bioemulsifier), twelve (12) also showed some enzymatic activity, corroborating about microorganisms that produce these compounds can have greater ability in the digestibility of the vegetal biomass. When comparing the obtained results among the isolated genera, it was possible to verify that Aspergillus sp. could be selected as a potential emulsifier producer, under the evaluated conditions of $\mathrm{E}_{24}$ indexes. Some species of Candida sp., Aspergillus sp., Cladosporium sp., Fusarium sp., Ustilago sp. and Trichosporon sp. were reported as able to produce compounds with these properties (Bhardwaj et al. 2013; Qazi et al. 2013; Castiglioni et al. 2009; Mulligan 2005; Desai and Banat 1997). According Lira (2014) fungal strains were able to detoxify the environment due to their abilities to join in organic matter. Kiran et al. (2009) showed biosurfactant production in A. ustus isolated from the marine sponge ( $E_{24}$ of $42.8 \%$ ).

Endophytic fungi have systems that can breakdown complex compounds, degrading chemical pollutants and exhibiting biosorption of heavy metals (Zhang et al. 2012; Li et al. 2012; Russell et al. 2011; Xiao et al. 2010). However, the knowledge about the bioemulsifier production by endophytic fungi is still very scarce. Only few studies were reported about this ability. Lima et al. (2016) showed emulsifier index of diesel oil (52\%) from Phoma sp. isolated from macrophytes at the Negro River, Manaus, Brazil. Other study with endophytic fungi isolated from Myrcia guianensis showed $\mathrm{E}_{24}$ values up to 75.75\% (Da Silva et al. 2014).

About the results of tensiometric analysis, in a similar study, reported by Reis et al. (2004), one isolated of Bacillus subtilis was able to produce surface tension of $28.7 \mathrm{mN} / \mathrm{m}$. Similarly, Qazi et al. (2013) exhibited surface tension of $32 \mathrm{mN} / \mathrm{m}$ from Fusarium sp. Moreover, by comparison surface tension breakdown obtained in the present study with synthetic surfactants, such SDSsodium dodecyl sulphate, that can reduce the surface tension from 72 to $37 \mathrm{mN} / \mathrm{m}$, it was verified that the obtained biosurfactant were efficient. This fact demonstrated that biosurfactants as potential as commercial surfactants, besides that it reduce the cost of production, has low toxicity, high biodegradability and environmental control (Kim et al. 2000).

Briefly, these results were possible to emphasize about the versatility of endophytic fungi, since enzymatic abilities, like oxidases and hydrolases that can to improve the lignocellulosic bioethanol production. Moreover, the production of metabolites with bioremediation potential, as biosurfactants and bioemulsifiers. Among the isolates, it is worth noting about the strain 47(4)-Trichoderma camerunense, which showed not only emulsifier and tensiometric activities, as well as a prominent cellulolytic and xylanolytic activities, turning it as a potential candidate for more investigations about future biotechnological applications.

\section{Acknowledgements}

This study was supported by the Brazilian research agencies FAPESP Processes (2004/13910-6 and 2016/23685-7) and CAPES. The authors would like to register their gratitude to UNIFESP (Federal University of São Paulo) and UFSCAR (Federal University of São Carlos) for financial and personal support.

\section{Authors' contributions}

Conceived and designed the experiments: VM, LMSL, MRZP, SPV. Performed the experiments: VM, LMSL, CAB, VBF, MRZP, LAS. Analyzed the data: VM, LMSL, MRZP, PTL, SPV. Contributed reagents/materials/financing support/analysis tools: FLLS, PTL, SPV. Wrote the paper: VM, LMSL, PTL, SPV. All authors read and approved the final manuscript.

\section{Funding}

This study was supported by the Brazilian research agencies FAPESP - Fundação de Amparo à Pesquisa do Estado de São Paulo (Processes 
2004/13910-6; 2010/51992-5; 2016/23685-7 and 2019/17883-9) and CAPES (scholarships code 001).

\section{Availability of data and materials}

The datasets used and/or analyzed during the current study are available from the corresponding author on reasonable request.

\section{Ethics approval and consents to participate}

The ethical committee of Federal University of São Paulo (CEP/UNIFESP) approved this work (Approval No. 3972131014). Additionally, the authors warrant that this manuscript represents original work that is not being considered for publication in any other vehicle of scientific divulgation. This manuscript does not infringe any other person's copyright or property rights.

\section{Consent for publication}

All authors are in agree for publication of the present manuscript.

\section{Competing interests}

The authors declare that they have no competing interests.

\section{Author details}

${ }^{1}$ Department of Pharmaceutical Sciences, Federal University of São Paulo (UNIFESP), R. São Nicolau, 210, Diadema, SP Zip Code 09913-030, Brazil. ${ }^{2}$ Latin American Institute of Life Sciences and Nature, Federal University of Latin American Integration, Av. Tarquínio Joslin dos Santos, 1000, Foz do Iguaçu, PR Zip Code 85870-901, Brazil. ${ }^{3}$ Laboratory of Microbiology and Biomolecules - LaMiB, Department of Morphology and Pathology, Center for Biological and Health Sciences, Federal University of São Carlos, Via Washington Luís km 235, PO BOX 676, São Carlos, SP 13565-905, Brazil.

Received: 9 May 2019 Accepted: 2 Auqust 2019

Published online: 19 August 2019

\section{References}

Aguiar A, Ferraz A (2011) Mecanismos envolvidos na biodegradação de materiais lignocelulósicos e aplicações tecnológicas correlatas. Quím Nova 34:1729-1738

Akbar MT, Habib AM, Chowdhury DUS, Bhuiyan MIK, Mostafa KMG, Mondol S, Mosleh IM (2013) An insight into the lignin peroxidase of Macrophomina phaseolina. Bioinformation 9:730-735

Andreote FD, Jiménez DJ, Chaves D, Dias AC, Luvizotto DM, Dini-Andreote F, Fasanella CC, Lopez MV, Baena S, Taketani RG, de Melo IS (2012) The microbiome of Brazilian mangrove sediments as revealed by metagenomics. PLoS ONE 7:38600

Aro N, Pakula T, Penttila M (2005) Transcriptional regulation of plant cell wall degradation by filamentous fungi. FEMS Microbiol Lett 29:719-739

Arora DS, Gill PK (2001) Comparison of two assay procedures for lignin peroxidase. Enzyme Microb Technol 28:602-605

Badola R, Primavera JH, Barbier E, Dahdouh-Guebas F (2008) Ethnobiology, socio-economics and management of mangrove forests: a review. Aquat Bot 89:220-236

Bansal N, Tewari R, Gupta JK, Soni R, Kumar Soni S (2011) A novel strain of Aspergillus niger producing a cocktail of hydrolytic depolymerizing enzymes for the production of second generation biofuels. Bioresources 6:552-569

Bezerra JDP, Santos MGS, Svedese VM, Lima DMM, Fernandes MJS, Paiva LM, Souza-Motta CM (2012) Richness of endophytic fungi isolated from Opuntia ficus-indica Mill. (Cactaceae) and preliminary screening for enzyme production. World J Microbiol Biotechnol 28:1989-1995

Bhardwaj G, Cameotra SS, Chopra HK (2013) Biosurfactants from fungi: a review. J Pet Environ Biotechnol 4:1-6

Bonugli-Santos RC, Durrant LR, Sette LD (2012) The production of ligninolytic enzymes by marine-derived basidiomycetes and their biotechnological potential in the biodegradation of recalcitrant pollutants and the treatment of textile effluents. Water Air Soil Pollut 223:2333-2345

Bourdour AA, Miller-Maier RM (1998) Application of a modified drop-collapse technique for surfactant quantitation and screening of biosurfactantproducing microorganisms. J Microbiol Method 32:273-280
Castiglioni GL, Bertolin TE, Costa JAV (2009) Produção de biossurfactante por Aspergillus fumigatus utilizando resíduos agro-industriais como substrato. Quím Nova 32:292-295

Cooper DG, Goldenberg BG (1987) Surface-active agents from two Bacillus species. Appl Environ Microbiol 53:224-229

D'Souza-Ticlo D, Verma AK, Mathew M, Raghukumar C (2006) Effect of nutrient nitrogen on laccase production, its isozyme pattern and effluent decolorization by the fungus NIOCC\# 2a, isolated from mangrove wood. Indian J Mar Sci 35:364-372

Da Silva MET, Nascimento CC, Junior SD, Albuquerque PM (2014) Biosurfactant production by Myrciaguianensis endophytic fungi. BMC Proc 8(Suppl 4):213

Das A, Paul T, Halder SK, Maity C, Mohapatra PKD, Pati BR, Mondal KC (2013) Study on regulation of growth and biosynthesis of cellulolytic enzymes from Newly isolated Aspergillus fumigatus ABK9. Pol J Microbiol 62:31-43

De Pinto MC, Ros Barceló A (1996) Inhibition of both peroxidase and laccase by desferal (desferrioxamine mesylate). Phytochemistry 42:283-286

Desai JD, Banat IM (1997) Microbial production of surfactants and their commercial potential. Microbiol Mol Biol Rev 61:47-64

Dias ACF, Andreote FD, Rigonato J, Fiore MF, Melo IS, Araújo WL (2010) The bacterial diversity in a Brazilian non-disturbed mangrove sediment. A Van Leeuw 98:541-551

Durán N (2010) Enzimas Ligninolíticas. In: Esposito E, Azevedo JL (eds) Fungos: Uma introdução à biologia, bioquímica e biotecnologia, 2nd edn. Educs, Caxias do Sul, p 638

Fernández-Fueyo E, Ruiz-Dueñas FJ, Martínez MJ, Romero A, Hammel KE, Medrano FJ, Martínez AT (2014) Ligninolytic peroxidase genes in the oyster mushroom genome: heterologous expression, molecular structure, catalytic and stability properties, and lignin-degrading ability. Biotechnol Biofuels 7:1-23

Fleck LC, Bicca FC, Ayub MAZ (2000) Physiological aspects of hydrocarbon emulsification, metal resistance and DNA profile of biodegrading bacteria isolated from oil polluted sites. Biotechnol Lett 22:285-289

Gajera HP, Bambharolia RP, Hirpava DG, Patel SV, Golakiya BA (2015) Molecular identification and characterization of novel Hypocrea koningii associated with azo dyes decolorization and biodegradation of textile dye effluents. Process Saf Environ Prot 98:406-416

Gottschalk LMF, Paredes RS, Teixeira RSS, Silva ASA, Bon EPS (2013) Efficient production of lignocellulotytic enzymes xylanase, $\beta$-xylosidase, ferulic acid esterase and $\beta$-glucosidase by the mutant strain Aspergillus awamori 2B.361 U2/1. Braz J Microbiol 44:569-576

Gouvêa PF (2013) Estudos genéticos e moleculares da produção de celulases e hemicelulases em Aspergillus nidulans e Aspergillus niger. Thesis, University of São Paulo

Heuts DPHM, Van Hellemond EW, Janssen DB, Fraaije MW (2007) Discovery, characterization, and kinetic analysis of an alditol oxidase from Streptomyces coelicolor. J Biol Chem 282:20283-20291

labal HMN, Ahmed I, Zia MA, Irfan M (2011) Purification and characterization of the kinetic parameters of cellulose produced from wheat straw by Trichoderma viride under SSF and its detergent compatibility. Adv Biosc Biotech 2:149-156

Kim SH, Lim EJ, Lee SO, Lee JD, Lee TH (2000) Purification and characterization of biosurfactants from Nocardia sp. L-417. Biotechnol Appl Biochem 31:249-253

Kiran GS, Hema TA, Gandhimathi R, Selvin J, Thomas TA, Rajeetha Ravji T, Natarajaseenivasan K (2009) Optimization and production of a biosurfactant from sponge-associated marine fungus Aspergillus ustus MSF3. Colloids Surf B Biointerfaces 73:250-256

Kirk O, Borchert TV, Fuglsang CC (2002) Industrial enzyme applications. Curr Opin Biotechnol 13:345-351

Kristensen E, Bouillon S, Dittmar T, Marchand C (2008) Organic carbon dynamics in mangrove ecosystems: a review. Aquat Bot 89:201-219

Kuwahara M, Glenn JK, Morgan MA, Gold MH (1984) Separation and characterization of two extracellular $\mathrm{H}_{2} \mathrm{O}_{2}$ - dependent oxidases from ligninolytic cultures of Phanerochaete chrysosporium. FEBS Lett 169:247-250

Li HY, Wei DQ, Shen M, Zhou ZP (2012) Endophytes and their role in phytoremediation. Fungal Divers 54:11-18

Lima JMS, Pereira JO, Batista IH, Costa Neto PQ, Dos Santos JC, De Araújo SP, Pantoja MC, Da Mota AJ, De Azevedo JL (2016) Potential biosurfactant producing endophytic and epiphytic fungi, isolated from macrophytes 
in the Negro River in Manaus, Amazonas, Brazil. Afr J Biotechnol 15:1217-1223

Lira DD (2014) Caracterização de Aspergillus sp. quanto a capacidade de degradação de óleo diesel. Dissertation, Federal University of Pernambuco

Lozovaya W, Lygin AV, Zernova OV, Widholm JM (2006) Lignin degradation by Fusarium solani f. sp. glycines. Plant Dis 90:77-82

Mabee WE, Saddler JN (2010) Bioethanol from lignocellulosics: status and perspectives in Canada. Bioresour Technol 101:4806-4813

Manavalan T, Manavalan A, Heese K (2015) Characterization of lignocellulolytic enzymes from white-rot fungi. Curr Microbiol 70:485-498

Michelin M, Peixoto-Nogueira SC, Betini JHA, Silva TM, Jorge JA, Terenzi HF, Polizeli MLTM (2010) Production and properties of xylanases from Aspergillus terricola Marchal and Aspergillus ochraceus and their use in cellulose pulp bleaching. Bioprocess Biosyst Eng 33:813-821

Mulligan CN (2005) Environmental applications for biosurfactants. Environ Pollut 133:183-198

Pacwa-Plociniczak M, Plaza GA, Piotrowska-Seget Z, Cameotra SS (2011) Environmental applications of biosurfactants: recent advances. Int J Mo Sci 12:633-654

Peixoto CRM, Rosa GR, Silva CN, Santos BT, Engelmann TL (2012) Miniprojeto para ensino de química geral experimental baseado na fermentação do caldo de cana-de-açúcar. Quím Nova 35:1686-1691

Polizeli MLTM, Corrêa ECP, Polizeli AM, Jorge JA (2011) Hydrolases from microorganisms used for degradation of plant cell wall and bioenergy. In: Buckeridge MS, Goldman GH (eds) Routes to cellulosic ethanol. Springer Science, New York, p 270

Qazi MA, Subhan M, Fatima N, Ali MI, Ahmed S (2013) Role of biosurfactant produced by Fusarium sp. BS-8 in enhanced oil recovery (EOR) through sand pack column. Int J Biosci Biochem Bioinform 3:598-604

Rabonato AC (2013) Linhagens Fúngicas na hidrólise enzimática de bagaço de cana-de-açúcar. 2013. Dissertation, Paulista State University

Rajulu MBG, Thirunavukkarasu N, Suryanarayanan TS, Ravishankar JP, Gueddari NEE, Moerschbacher BM (2011) Chitinolytic enzymes from endophytic fungi. Fungal Divers 47:43-53

Reis FAS, Sérvulo EFC, França FP (2004) Lipopeptide surfactant production by Bacillus subtilis grown on low-cost raw materials. Appl Biochem Biotechnol 113:899-912

Rodrigues LR, Teixeira JA, Van der Mei HC, Oliveira R (2006) Physicochemical and functional characterization of a biosurfactant produced by Lactococcus lactis 53. Colloids Surf B Biointerfaces 49:79-86

Russell JR, Huang J, Anand P, Kucera K, Sandoval AG, Dantzler KW, Hickman D, Jee J, Kimovec FM, Koppstein D, Marks DH, Mittermiller PA, Núñez SJ, Santiago M, Townes MA, Vishnevetsky M, Williams NE, Vargas MPN, Boulanger L, Bascom-Slack C, Strobel SA (2011) Biodegradation of polyester polyurethane by endophytic fungi. Appl Environ Microbiol 77:6076-6084

Schwarz M, Kopcke B, Weber RWS, Sterner O, Anke H (2004) 3-Hydroxypropionic acid a nematicidal principle in endophytic fungi. Phytochem 65:2239-2245

Sebastianes FLS (2010) Diversidade genética e potencial biotecnológico de fungos endofíticos de manguezais do estado de São Paulo. Thesis, University of São Paulo
Sebastianes FLS, Romão-Dumaresq AS, Lacava PT, Harakava R, Azevedo JL, Melo IS, Pizzirani-Kleiner AA (2013) Species diversity of culturable endophytic fungi from Brazilian mangrove forests. Curr Genet 59:153-166

Shraddha S, Shekher R, Sehgal S, Kamthania M, Kumar A (2011) Laccase: microbial sources, production, purification, and potencial biotechnological applications. Enzyme Res 2011:1-11

Silva MLC, De Souza VB, Santos VS, Kamida HM, De Vasconcellos-Neto JRT, Góes-Neto A, Koblitz MGB (2014) Production of manganese peroxidase by Trametes villosa on unexpensive substrate and its application in the removal of lignin from agricultural wastes. Adv Biosci Biotechnol 5:1067-1077

Soberón-Chávez G, Maier RM (2011) Biosurfactants: a general overview. In: Soberón-Chávez G (ed) Biosurfactants: from genes to applications. Springer, Berlin, pp 1-11

Sousa OV, Macrae A, Menezes FGR, Gomes NCM, Vieira RHSF, MendonçaHagler LCS (2006) The impact of shrimp farming effluent on bacterial communities in mangrove waters, Ceará, Brazil. Mar Pollut Bull 52:1725-1734

Stoilova I, Krastanov A, Stanchev V (2010) Properties of crude laccase from Trametes versicolor produced by solid-substrate fermentation. Adv Biosci Biotechnol 1:208-215

Tooley L, Roberts J (2016) Evaluation of VOC producing Diaporthe sp. for enzyme production. In: Annual meeting global science engagement. https://aaas.confex.com/aaas/2016/webprogram/Paper18264.html. Accessed 06 June 2017

Wang M, Li Z, Fang X, Wang L, Qu Y (2012) Cellulolytic enzyme production and enzymatic hydrolysis for second-generation bioethanol production. Adv Biochem Eng Biotechnol 128:1-24

Xiao X, Luo S, Zeng G, Wei W, Wan Y, Chen L, Guo H, Cao Z, Yang L, Chen J, Xi $\mathrm{Q}$ (2010) Biosorption of cadmium by endophytic fungus (EF) Microsphaeropsis sp. LSE10 isolated from cadmium hyperaccumulator Solanum nigrum L. Bioresour Technol 101:1668-1674

Zhang X, Lin L, Chen M, Zhu Z, Yang W, Chen B, Yang X, An Q (2012) A nonpathogenic Fusarium oxysporum strain enhances phytoextraction of heavy metals by the hyperaccumulator Sedum alfredii Hance. J Hazard Mater 229:361-370

Zhao XQ, Zi LH, Bai FW, Lin HL, Hao XM, Yue GJ, Ho NWY (2012) Bioethanol from lignocellulosic biomass. Adv Biochem Eng Biotechnol 128:25-51

Zheng Y-K, Qiao X-G, Miao C-P, Liu K, Chen Y-W, Xu L-H, Zhao L-X (2016) Diversity, distribution and biotechnological potential of endophytic fungi. Ann Microbiol 66:529-542

\section{Publisher's Note}

Springer Nature remains neutral with regard to jurisdictional claims in published maps and institutional affiliations.

\section{Submit your manuscript to a SpringerOpen ${ }^{\circ}$ journal and benefit from:}

- Convenient online submission

- Rigorous peer review

- Open access: articles freely available online

- High visibility within the field

Retaining the copyright to your article

Submit your next manuscript at $\boldsymbol{\nabla}$ springeropen.com 